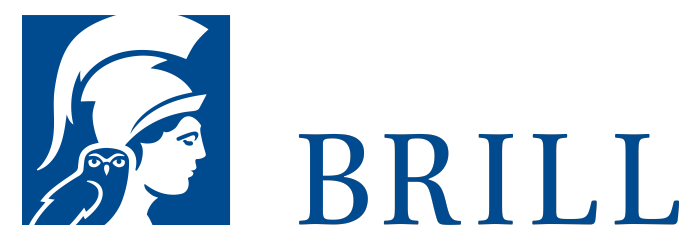

\title{
JT Wilson and the Fraternity of Duckmaloi
}

\section{Author: Patricia Morison}

In the 189os four young scientists at Sydney University - two Scots, a Londoner and an Australian - began sustained research into Australian native fauna for which each was awarded the FRS. They all went on to pursue notable careers in the biological sciences, concluding in London 46-8 and Cambridge. This book follows their careers and enduring friendship exploring in detail the life of its senior member, J.T. Wilson (1861-1945), who was professor of anatomy at Sydney University (1890-1920) and Cambridge (1920-1933) and had abiding interests in science, philosophy, education and military affairs. The narrative is mainly concerned with issues of historical interest to scientists and medical educationists though some, like Empire relations and the contribution of Scots to Australia's development, will interest a wider readership. Many of the preoccupations of Wilson and his colleagues remain topical: the debate between biological science and religion; the struggle to interpret Darwin's theory without placing Homo sapiens at the top of an evolutionary tree; pure versus applied science; vocationalism versusscholarship in university education.

\section{Readership}

The book is of historical interest to scientists and medical educationists though some, like Empire relations and the contribution of Scots to Australia's development, will interest a wider readership.

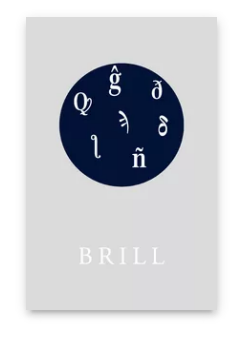

Pages: xiii, 474 pp.

Language:

English

Subjects:

History of

Medicine,

History,

Contemporary

History, History

Publisher: Brill

Series:

Clio Medica

Online, Volume:

42

Clio Medica,

Volume: 42

E-Book (PDF)

Released online:

o1 Dec 2019

ISBN: 978-90-

04-41852-3

Hardback

Publication date:

o1 Jan 1997

ISBN: 978-90-

420-0232- 6

Paperback

Publication date:

o1 Jan 1997

ISBN: 978-90-

420-0246-3

List price 
For more information see brill.com

Order information: Order online at brill.com +44330 3330049 | customerservices@brill.com Submission information: brill.com/authors

Titles published by Brill | Fink, Brill | mentis or Brill | Schöningh: +49(o)71 5413279216 | brill@brocom.de 